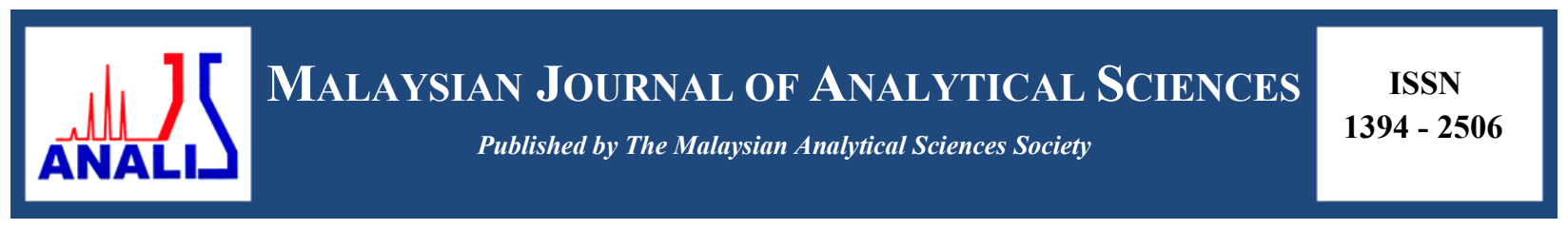

\title{
CRUDE PALM OIL BIODIESEL BY TRANSESTERIFICATION PROCESS USING CHOLINE HYDROXIDE CATALYST
}

\author{
(Biodiesel Minyak Sawit Mentah Melalui Proses Transesterifikasi Menggunakan Mangkin Kolin \\ Hidroksida)
}

\author{
Renita Manurung*, Nadya G. Bestari, Dania K. Syabri \\ Department of Chemical Engineering, Faculty of Engineering, \\ Universitas Sumatera Utara, 20155 Medan, Sumatera, Indonesia
}

*Corresponding author: renitachem@yahoo.com

Received: 21 October 2015; Accepted: 14 June 2016

\begin{abstract}
Biodiesel is generally made by transesterification using alkaline catalyst. Choice of catalyst used greatly affects the biodiesel produced. Choline Hydroxide $(\mathrm{ChOH})$ catalyst is a basic ionic liquid having excellent catalytic reactions in the synthesis of palm biodiesel from Crude Palm Oil (CPO). This catalyst is able to produce biodiesel without soap formation which at the end of the reaction, three layers formed. They are biodiesel, the catalyst itself and glycerol. This makes it easy to separate biodiesel from the by product. Several other important variables in addition to the choice of catalyst and is catalyst dosage, molar ratio of ethanol to CPO and reaction time. The highest yield of biodiesel produced is $99.84 \%$ with molar ratio of ethanol to CPO is $9: 1$, reaction time is 90 minutes, $5.5 \%$ catalyst $(\mathrm{w} / \mathrm{w})$ at $70{ }^{\circ} \mathrm{C}$ and $400 \mathrm{rpm}$ stirring speed. The most influential variable is catalyst dosages that give the significant difference yield of biodiesel produced. It evidenced by more dosages of catalyst used will provide a higher yield of biodiesel.
\end{abstract}

Keywords: choline hydroxide, crude palm oil, ethanol, ionic liquid, palm biodiesel

\begin{abstract}
Abstrak
Biodiesel umumnya dihasilkan secara transesterifikasi menggunakan mangkin beralkali. Pilihan mangkin yang digunakan sangat mempengaruhi biodiesel yang dihasilkan. Kolin hidroksida $(\mathrm{ChOH})$ adalah cairan ionik bes yang memiliki tindak balas pemangkinan yang sangat baik dalam sintesis biodiesel sawit dari minyak sawit mentah (CPO). Mangkin ini mampu menghasilkan biodiesel tanpa pembentukan sabun di mana pada akhir tindak balas membentuk tiga lapisan. Lapisan tersebut adalah biodiesel, mangkin itu sendiri dan gliserol. Hal ini memudahkan pemisahan biodiesel dari produk sampingan tersebut. Beberapa pemboleh ubah penting selain pilihan mangkin adalah dos mangkin, nisbah molar etanol terhadap CPO dan masa tindak balas. Hasil tertinggi dari biodiesel adalah 99.84\% dengan nisbah molar etanol terhadap CPO adalah 9:1, masa tindak balas 90 minit, 5.5\% mangkin $(\mathrm{w} / \mathrm{w})$ pada $70{ }^{\circ} \mathrm{C}$ dan kelajuan putaran $400 \mathrm{rpm}$. Pemboleh ubah yang paling berpengaruh adalah dos mangkin yang memberikan perbezaan hasil yang signifikan terhadap biodiesel yang dihasilkan. Ini membuktikan dengan semakin banyak dos mangkin yang digunakan akan memberikan hasil biodiesel yang lebih tinggi.
\end{abstract}

Kata kunci: kolin hidroksida, minyak sawit mentah, etanol, cecair ionik, biodiesel sawit

\section{Introduction}

Biodiesel, an alternative diesel fuel, is made from renewable biological sources such as vegetable oils and animal fats. It is biodegradable and nontoxic, has low emission profiles and so is environmentally beneficial [1]. According to the statistics, $70 \%$ of manufacturing cost in producing biodiesel is contributed by feedstock [2]. Indonesia has a 
big potential for producing biodiesel because the developments in Indonesia's Crude Palm Oil (CPO) production is increasing every year.

Biodiesel is mostly produced by a transesterification reaction, from oil with an alcohol and the presence of a catalyst to generate mono-alkyl esters and glycerol, which are then separated and purified [3]. Alcohols such as methanol and ethanol are the most commonly used. The yield of biodiesel using ethanol as alcohol reactant and $\mathrm{ChOH}$ catalyst is higher than using methanol as alcohol reactant [4]. In addition, ethanol can be produced from renewable agricultural resources [5]. So the use of ethyl esters is more environmentally friendly than the use of methyl ester.

Ionic liquids have been successfully used as a catalyst to catalyze transesterification reaction towards biodiesel production with good performance, higher conversion and selective production of biodiesel and glycerol conversion [6]. Ionic liquids are organic salts with a low melting point and very low vapor pressure [7]. Choline hydroxide $(\mathrm{ChOH})$ catalyst exhibited better catalytic activity compared with other basic ionic liquid catalysts [8]. Ionic liquidbased catalyst choline does not cause the formation of soap. Reaction conditions such as temperature, time, molar ratio and dose of catalyst are optimized to obtain highest conversion in producing biodiesel [9]. The structure $\mathrm{ChOH}$ shows the presence of ion $\mathrm{OH}^{-}$in Figure 1.

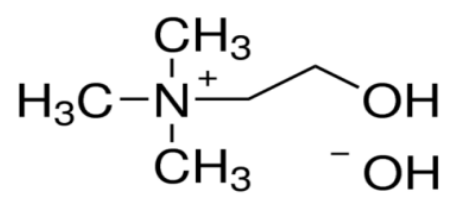

Figure 1. The ionization structure of choline hydroxide

\section{Materials and Methods}

The raw materials used are crude palm oil (CPO) obtained from PT Perkebunan Nusantara IV (PTPN IV). Alcohol used is ethanol $\left(\mathrm{C}_{2} \mathrm{H}_{5} \mathrm{OH}\right)$ and choline hydroxide $(\mathrm{ChOH})$ was used as catalyst. Transesterification reaction is carried out by the stirring speed $400 \mathrm{rpm}$ and a constant temperature of $70^{\circ} \mathrm{C}$ with process variables as follows: 1) dose of catalyst, 2) the molar ratio of ethanol:CPO and 3) reaction time.

CPO with a certain amount of weight is weighed and followed by the preparation of ethanol and a catalyst $\mathrm{ChOH}$. $\mathrm{CPO}$ and ethanol were mixed at a specific molar ratio in a flask equipped with reflux condenser, thermometer and stirrer. Afterwards, $\mathrm{ChOH}$ was added and the mixture was stirred and heated using a hot plate till a constant temperature was reached. After that, the mixture was separated using a separator funnel until 2-3 layers were formed, then washed until the washed water is clear. Analysis can be performed after the ethyl ester prepared.

Factors that influence the reaction such as catalyst dosage, molar ratio of ethanol toward CPO and reaction time were analyzed systematically with the response surface methodology (RSM) with a central composite design (CCD). Level code and the combination of research can be seen in Table 1 and Table 2, respectively. Design equation models offered during the three factors which are as follows [10].

$$
Y=\beta_{1}+\beta_{2} \chi_{1}+\beta_{3} \chi_{2}+\beta_{4} \chi_{3}+\beta_{5} \chi_{1} \chi_{2}+\beta_{6} \chi_{2} \chi_{3}+\beta_{7} \chi_{1} \chi_{3}+\beta_{8} \chi_{1}^{2}+\beta_{9} \chi_{2}^{2}+\beta_{10} \chi_{3}^{2}+\varepsilon
$$

Table 1. Level code on experimental design

\begin{tabular}{lcccccc}
\hline \multirow{2}{*}{ Variables } & \multirow{6}{*}{ Code } & \multicolumn{5}{c}{ Levels } \\
\cline { 3 - 7 } & & $\mathbf{- 1 . 6 7 3}$ & $\mathbf{- 1}$ & $\mathbf{0}$ & $\mathbf{1}$ & $\mathbf{1 . 6 7 3}$ \\
\hline Catalyst Dosage (w/w) & $\mathrm{X}_{1}$ & 2.5 & 3 & 4 & 5 & 5.5 \\
Molar Ratio Ethanol:CPO & $\mathrm{X}_{2}$ & $4: 1$ & $6: 1$ & $9: 1$ & $12: 1$ & $14: 1$ \\
Reaction Time (min) & $\mathrm{X}_{3}$ & 40 & 60 & 90 & 120 & 140 \\
\hline
\end{tabular}


Table 2. Central Composite Design for Three Variables

\begin{tabular}{cccc}
\hline No & $\begin{array}{c}\text { Dose of Catalyst } \\
(\mathbf{w} / \mathbf{w})\end{array}$ & $\begin{array}{c}\text { Molar Ratio } \\
\text { Ethanol:CPO }\end{array}$ & $\begin{array}{c}\text { Reaction Time } \\
\text { (minute) }\end{array}$ \\
\hline 1 & -1 & -1 & -1 \\
2 & -1 & 1 & 1 \\
3 & 1 & -1 & 1 \\
4 & 1 & 1 & -1 \\
5 & 0 & 0 & 0 \\
6 & -1 & -1 & 1 \\
7 & -1 & 1 & -1 \\
8 & 1 & -1 & -1 \\
9 & 1 & 1 & 1 \\
10 & 0 & 0 & 0 \\
11 & -1.673 & 0 & 0 \\
12 & 1.673 & 0 & 0 \\
13 & 0 & -1.673 & 0 \\
14 & 0 & 1.673 & 0 \\
15 & 0 & 0 & -1.673 \\
16 & 0 & 0 & 1.673 \\
17 & 0 & 0 & 0 \\
\hline
\end{tabular}

\section{Results and Discussion}

\section{Free fatty acid (FFA) and water content}

Analysis free fatty acids and moisture have been done to raw materials CPO. Comparative analysis of the levels of free fatty acids for CPO against palm oil degummed (DPO) can be seen in Figure 2.

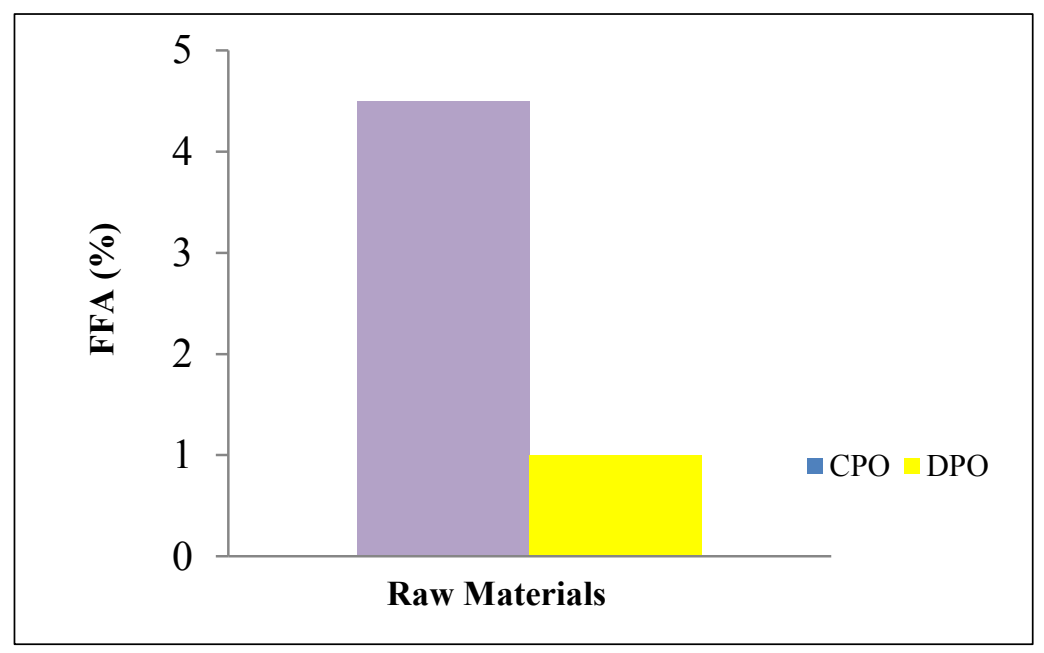

Figure 2. Free fatty acid level 


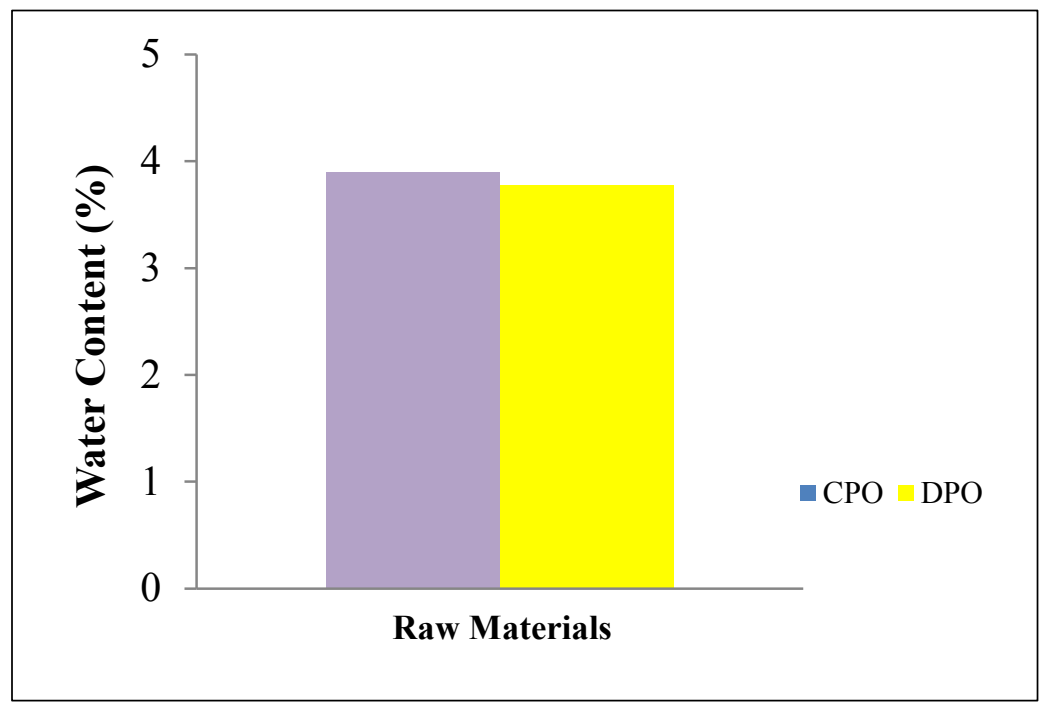

Figure 3. Water content

Low water content can generate higher products conversion. In addition to FFA and water, CPO also contain gum that can interfere the performance of the catalyst, therefore $\mathrm{CPO}$ needs to be degummed.

\section{CPO as the raw material}

Preliminary research has been done on CPO and DPO as basic of raw material selection. With the same reaction conditions, \% yield of the ethyl ester of CPO and DPO can be seen as shown in Figure 4.

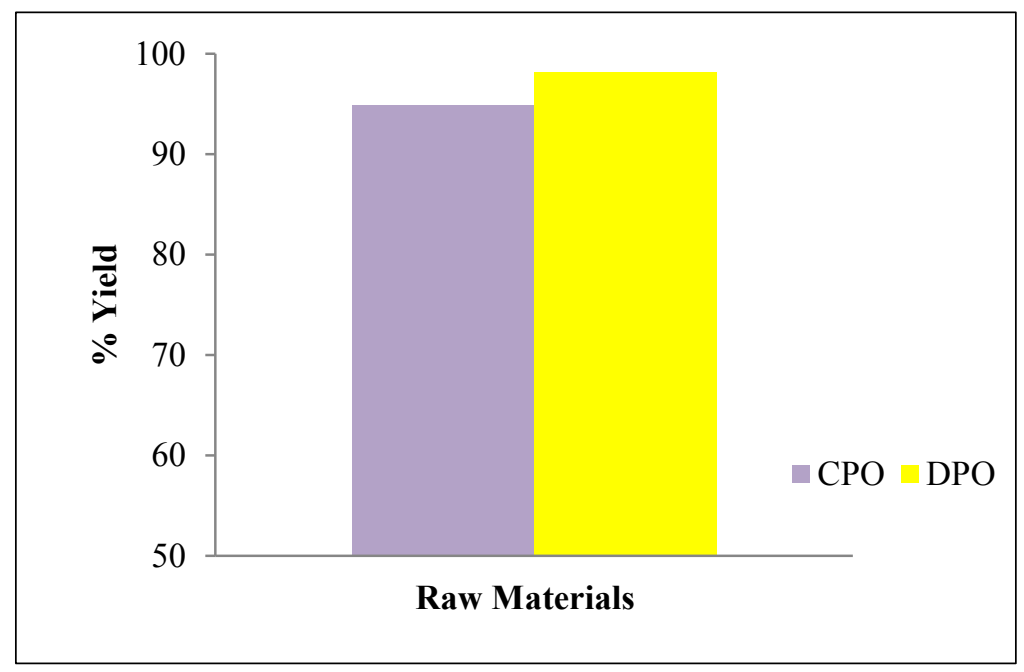

Figure 4. Percentage yield ethyl ester of CPO and DPO

Figure 4 shows the percentage yield of ethyl ester of CPO and DPO with reaction temperature at $70{ }^{\circ} \mathrm{C}$ and a stirring speed $400 \mathrm{rpm}$. Catalyst dosage used was $4 \%(\mathrm{w} / \mathrm{w})$, molar ratio of ethanol against the raw material is 9:1 
and reaction time is 90 minutes. Percentage yield of DPO is 98.17 and 94.92 for CPO. Based on the data above, the raw materials are selected in this study is the $\mathrm{CPO}$ as percentage yield obtained from the experiment is not too far difference from DPO. With the high FFA and high water content of $\mathrm{CPO}$, the ionic liquid $\mathrm{ChOH}$ able to catalyze the transesterification reaction very well, with percentage yield of ethyl ester is $94.92 \%$.

Manufacturing biodiesel from CPO, as raw materials without pre-treatment is able to lower production costs. The cost of raw materials contributes about $70 \%$ of the total cost of production. Pre-treatment CPO make the preparation of raw material more complex, so the cost of it as raw material higher than no pre-treatment CPO. Therefore, using $\mathrm{CPO}$ as raw material for biodiesel production was instrumental in lowering the total cost of production so that the price of biodiesel can be predicted cheaper.

\section{Effect of process variables toward percentage yield}

Following the experimental results data in a central composite design and the combination of the research can be seen in Table 3.

Table 3. Yield ethyl ester in central composite design

\begin{tabular}{ccccc}
\hline No & $\begin{array}{c}\text { Dose of Catalyst } \\
(\mathbf{w} / \mathbf{w})\end{array}$ & $\begin{array}{c}\text { Molar Ratio } \\
\text { Ethanol:CPO }\end{array}$ & $\begin{array}{c}\text { Reaction Time } \\
\text { (minute) }\end{array}$ & \% Yield \\
\hline 1 & -1 & -1 & -1 & 63.578 \\
2 & -1 & 1 & 1 & 95.318 \\
3 & 1 & -1 & 1 & 97.930 \\
4 & 1 & 1 & -1 & 97.070 \\
5 & 0 & 0 & 0 & 98.174 \\
6 & -1 & -1 & 1 & 60.500 \\
7 & -1 & 1 & -1 & 97.569 \\
8 & 1 & -1 & -1 & 97.002 \\
9 & 1 & 1 & 1 & 97.538 \\
10 & 0 & 0 & 0 & 98.174 \\
11 & -1.673 & 0 & 0 & 61.296 \\
12 & 1.673 & 0 & 0 & 99.845 \\
13 & 0 & -1.673 & 0 & 99.505 \\
14 & 0 & 1.673 & 0 & 98.907 \\
15 & 0 & 0 & -1.673 & 96.653 \\
16 & 0 & 0 & 1.673 & 65.870 \\
17 & 0 & 0 & 0 & 98.174 \\
\hline
\end{tabular}

Experimental data were analyzed using STATISTICA program, to get the parameters from the model that will provide the estimation of influence of variables against ethyl ester percentage yield. Statistical analysis to determine the significant influence of variables is shown in Table 4. 
Table 4. Regression coefficients

\begin{tabular}{lcccc}
\hline $\begin{array}{l}\text { Model } \\
\text { Parameter }\end{array}$ & $\begin{array}{c}\text { Parameter } \\
\text { Estimate }\end{array}$ & $\begin{array}{c}\text { Standard } \\
\text { Error }\end{array}$ & $\begin{array}{c}\text { Computed } \\
\text { T-Value }\end{array}$ & $\boldsymbol{P}$-Value \\
\hline Intercept & 97.617 & 5.188 & 18.813 & $2.35 \times 10^{-7}$ \\
$\mathrm{X}_{1}$ & 20.863 & 5.148 & 4.052 & 0.004 \\
$\mathrm{X}_{2}$ & -13.147 & 6.377 & -2.061 & 0.078 \\
$\mathrm{X}_{3}$ & 9.957 & 4.943 & 2.014 & 0.083 \\
$\mathrm{X}_{1}{ }^{2}$ & 2.459 & 5.408 & 0.454 & 0.662 \\
$\mathrm{X}_{2}{ }^{2}$ & -8.149 & 4.943 & -1.648 & 0.143 \\
$\mathrm{X}_{3}{ }^{2}$ & -10.460 & 5.408 & -1.934 & 0.094 \\
$\mathrm{X}_{1} \mathrm{X}_{2}$ & -17.282 & 6.435 & -2.685 & 0.031 \\
$\mathrm{X}_{1} \mathrm{X}_{3}$ & 1.681 & 6.435 & 0.261 & 0.801 \\
$\mathrm{X}_{2} \mathrm{X}_{3}$ & 0.091 & 6.435 & 0.014 & 0.989 \\
\hline
\end{tabular}

Based on the Table 4, the most significant parameter is the dose of the catalyst and combination of catalyst dosage and molar ratio ethanol to CPO. Since p-value is 0.05 , the other parameter is considering as insignificant. Polynomial equation is expressed as equation 2 below.

$$
\mathrm{Y}_{\text {yield }}=976179+208637 \mathrm{X}_{1}-131470 \mathrm{X}_{2}+24599 \mathrm{X}_{1}^{2}-172828 \mathrm{X}_{1} \mathrm{X}_{2}
$$

The experimental data are shown in graphical form contour plot that showing the relationship the two variables against percentage yield (see Figure 5,6 and 7). Figure 5 shows the relationship between the dose of the catalyst and the molar ratio of ethanol to $\mathrm{CPO}$ against percentage yield of ethyl esters. Based on the graph, it shows that the effect is given by catalyst dosage to the percentage yield of ethyl esters greater than molar ratio. The greater dose of the catalyst makes the process of converting oil into ethyl ester higher. Low doses of catalysts can also produce biodiesel with high yields but is followed by the amount of the molar ratio of ethanol: CPO. The use of catalysts with high enough doses followed by the high molar ratio of ethanol to CPO can raise percentage yield of ethyl ester.

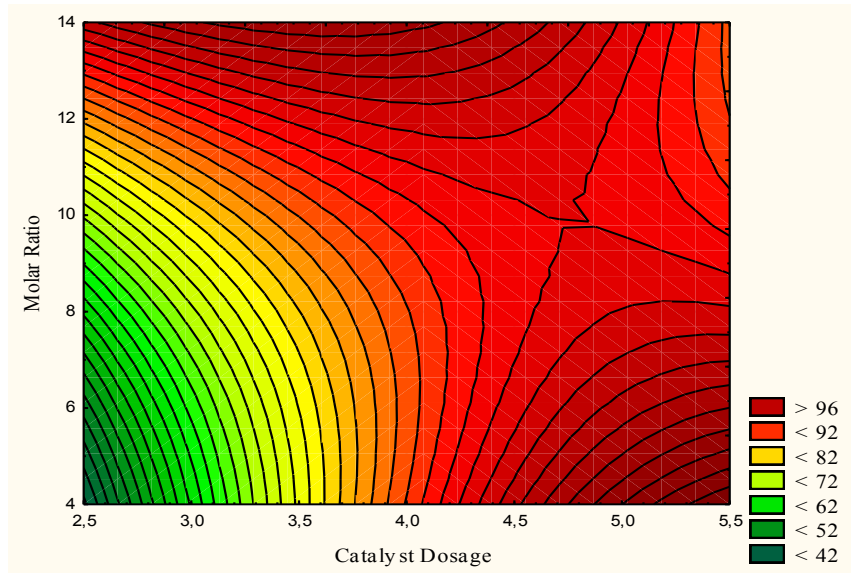

Figure 5. Contour plot of catalyst dosage and molar ratio ethanol: CPO against percentage yield 
Figure 6 shows the relationship between the dose of the catalyst and reaction time against percentage yield. In this figure, it can be seen that the use of catalysts $\mathrm{ChOH}$ with high enough doses, the conversion of triglycerides into biodiesel is also high, but must be followed by the optimal reaction time. If the transesterification reaction time is too long exceeding the optimum time, the conversion of the resulting biodiesel can be low. For a short time, the biodiesel produced is high enough so that the use of catalysts $\mathrm{ChOH}$ is very advantageous in biodiesel transesterification reaction. The catalyst dosage and reaction time effect on yield greatly significant.

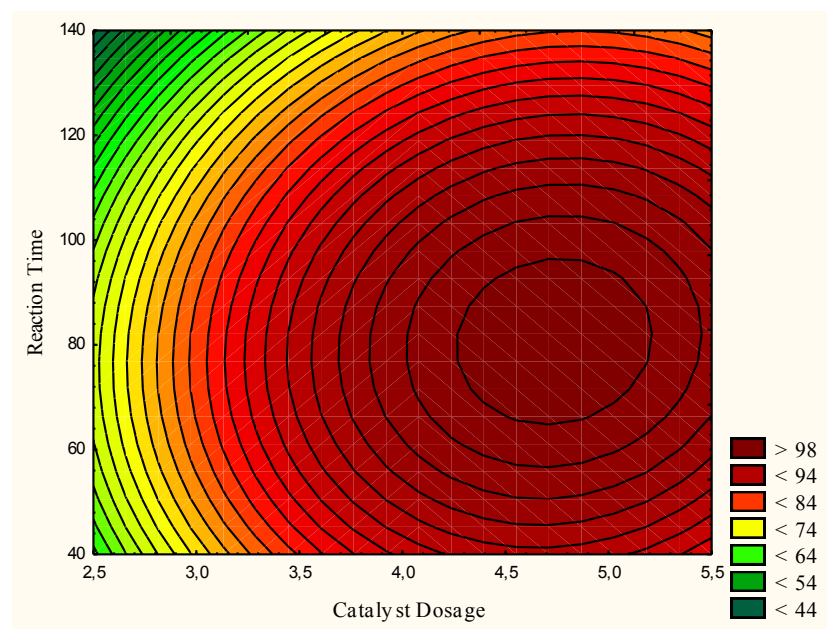

Figure 6. Contour plot of catalyst dosage and reaction time against percentage yield

Figure 7 shows the relationship between the molar ratio of ethanol: CPO and reaction time against percentage yield of ethyl ester. From this contour plot, it can be seen that the high molar ratio of ethanol to CPO, can produce biodiesel with a high percentage yield. As for the reaction time, on the contrary, the long reaction times, can cause biodiesel produced is low. Transesterification short reaction time is sufficient to produce the high percentage yield of ethyl ester. Effect of reaction time on biodiesel is more dominant than the molar ratio of ethanol to CPO.

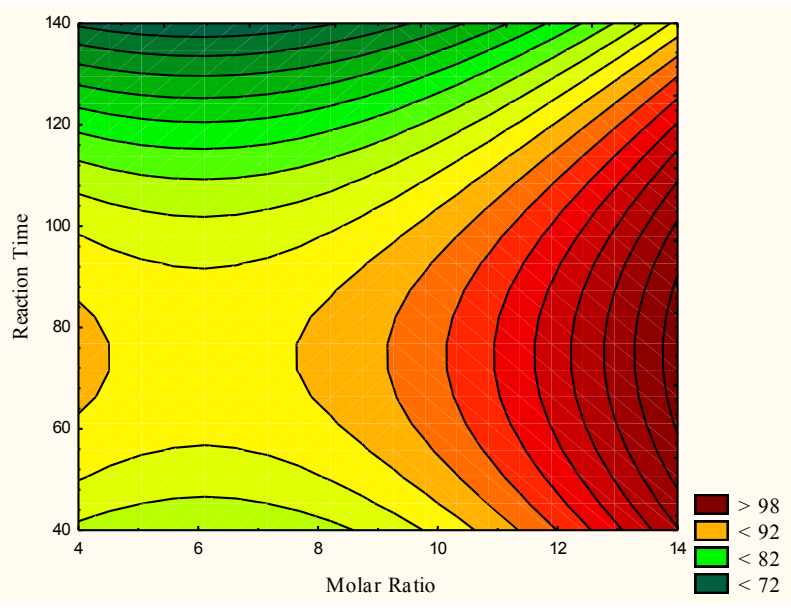

Figure 7. Contour plot of molar ratio ethanol: $\mathrm{CPO}$ and reaction time against percentage yield 


\section{Manurung et al: CRUDE PALM OIL BIODIESEL BY TRANSESTERIFICATION PROCESS USING CHOLINE HYDROXIDE CATALYST}

\section{Conclusion}

$\mathrm{CPO}$ as feedstock in biodiesel production without going through the pre-treatment can produce good enough yields of biodiesel using a basic catalyst ionic liquid choline hydroxide $(\mathrm{ChOH})$. Ethanol has great potential in biodiesel production as a reactant alcohol because it is renewable and included in agricultural cycle. The optimum point in biodiesel production is $99.84 \%$ at $70{ }^{\circ} \mathrm{C}$ with a molar ratio of ethanol against crude palm oil was $9: 1$, the catalyst dosage $5.5 \%(\mathrm{w} / \mathrm{w})$ and the reaction time is 90 minutes. The variables that most influence are the catalyst dosage followed by reaction time and the molar ratio. The lower of catalyst dosage and more doses of catalyst and molar ratio of ethanol: CPO will produce higher percentage yield.

\section{Acknowledgement}

The facilities supports from Chemical Process Laboratory, Department of Chemical Engineering, Faculty of Engineering, University of Sumatera Utara, North Sumatera, Medan 20155, Indonesia.

\section{References}

1. Ma, F. and Hanna, M. A. (1999). Biodiesel production: A review. Bioresource Technology, 70(1): $1-15$.

2. Izah, S. C. and Ohimain, E. I. (2013). The challenge of biodiesel production from oil palm feedstock in Nigeria. Greener Journal of Biological Sciences, 3(1): 1 - 12.

3. Taufiq-Yap, Y. H., Abdullah, N. F. and Basri, M. (2011). Biodiesel production via transesterification of Palm oil using $\mathrm{NaOH} / \mathrm{Al}_{2} \mathrm{O}_{3}$ catalysts. Sains Malaysiana, 40(6): 587 - 594.

4. Manurung, R., Dania K. S. and Nadya G. B. (2015). Methyl ester as biodiesel from crude palm oil (CPO) using choline hydroxide catalyst. Proceeding of the $22^{\text {nd }}$ Regional Symposium on Chemical Engineering, Malaysia.

5. Suppalakpanya, K., Ratanawilai, S., Nikhom, R. and Tongurai, C. (2011). Production of ethyl ester from crude palm oil by two-step reaction using continuous microwave system. Sonklanakarin Journal of Science and Technology, 33(1): $79-86$.

6. Ishak, Z. I., Sairi, N. A., Alias, Y., Aroua, M. K. T and Yusoff, R. (2014). Ionic liquids as green catalysts for transesterification reactions to produce biodiesel and glycerol carbonate - a review. Processing Technology.

7. Van Doorslaer, C., Wahlen, J., Mertens, P., Binnemans, K. and De Vos, D. (2010). Immobilization of molecular catalysts in supported ionic liquid phases. Dalton Transactions, 39(36): 8377 - 8390.

8. Fan, M., Huang, J., Yang, J. and Zhang, P. (2013). Biodiesel production by transesterification catalyzed by an efficient choline ionic liquid catalyst. Applied Energy, 108: 333 - 339.

9. Reddy, E. R., Sharma, M., Chaudhary, J. P., Bosamiya, H. and Meena, R. (2014). One-pot synthesis of biodiesel from high fatty acid Jatropha curcas oil using bio-based basic ionic liquid as a catalyst. Current Science, 106(10): $1394-1400$.

10. Manurung, R. (2005). Optimasi dan kinetika transesterifikasi minyak sawit menjadi etil ester. Thesis Magister Teknik Kimia, 24: pp. 30 - 34. 